\title{
Kulturarteko harremanak Bigarren Hezkuntzan: ikasle etorkin eta bertakoen akulturazio-orientazioak ${ }^{1}$
}

\author{
Naiara Berasategi Sancho \\ Didaktika eta Eskola Antolakuntza Saila \\ Bilboko Irakasleen U.E. \\ Euskal Herriko Unibertsitatea UPV/EHU \\ Nekane Larrañaga Aizpuru \\ Soziologia eta Gizarte Langintza Saila \\ Hezkuntza, Filosofia eta Antropologia Fakultatea \\ Euskal Herriko Unibertsitatea UPV/EHU \\ Iñaki García Fernández \\ María José Azurmendi Ayerbe \\ Gizarte-Psikologia eta Portaera Zientzien Metodologia Saila \\ Hezkuntza, Filosofia eta Antropologia Fakultatea \\ Euskal Herriko Unibertsitatea UPV/EHU
}

DOI: $10.1387 /$ tantak.17481

GAKO-HITZAK: Derrigorrezko Bigarren Hezkuntza, akulturazio-orientazioak, jatorria, identitate etnolinguistikoa.

\section{SARRERA}

\section{Akulturazio-Orientazioak}

Migrazio-mugimenduen ondorioz sortzen diren kultur talde ezberdinen arteko ukipen-egoerak geroz eta ugariagoak bihurtu dira Europan, baita Euskal Herrian ere. Prozesu horiek esplikatzeko, akulturazioaren teoriak

\footnotetext{
${ }^{1}$ Ikerlan honek Euskal Herriko Unibertsitatearen diru-laguntza jaso du 2010eko deialdian (UPV/EHU 10/21).
} 
garatu dira. Akulturazioa esaten zaio bi edo hainbat kultur talderen arteko zuzeneko ukipen-egoeratik sortzen den aldaketa kulturalari (Berry, 1997).

Hasiera batean akulturazioa norabide bakarreko prozesu lineal bat bezala ulertzen zen; espero zen etorkinek harrera-gizartearekiko egokitze-bidea egitea eta asimilazio-orientazioarekin parekatzen zen. Geroago, ordea, akulturazioa norabide bikoitzeko prozesu bezala ulertua izatera iritsi da, eta harrera-gizartea nahiz etorkin-taldea elkar eraginean egonik, bi kulturek aldaketak izango dituztela onartzen da (Sam, 2006). Horregatik, garrantzitsua da, etorkinek kultura berriarekiko dituzten jarrerak aztertzeaz gain, harrera-gizarteak etorkin horiekiko dituzten akulturazio-itxaropenak edo usteak ere kontuan izatea (Berry, 2001; Van Oudenhoven, Ward eta Masgoret, 2006).

Bigarren ikuspegiarekin lotzen da Interactive Acculturation Model (IAM) izeneko eredu teorikoa (Bourhis, Moise, Perreault eta Senecal, 1997). IAM ereduaren arabera harrera-gizartearen akulturazio-orientazioek eragin ahal diote etorkinen akulturazio-orientazioei.

Horrela, harrera-gizartearen ikuspegitik, akulturazio-orientazio horiek bost modutan gerta daitezke: integrazioa, asimilazioa, segregazioa, esklusioa eta indibidualismoa. Integrazioaren kasuan, etorkinen taldearen eta harrera-taldearen hizkuntzak eta kulturak egoera harmoniatsuan egongo lirateke. Asimilazioan, etorkinen taldeak harrera-taldearen hizkuntza eta kultura bereganatu behar luke bere kulturari eta hizkuntzari uko eginez. Segregazioan, etorkinen taldeak bere kultura eta hizkuntza mantenduko lituzke, harrera-taldeko kideekin harremanik izan gabe. Esklusioan, etorkinek ezingo lukete beren kultura eta hizkuntza mantendu eta gainera ez lukete harrera taldearekin harremanik izango. Azkenik, indibidualismoan, norbanakoa ez da ulertzen talde bateko kide moduan baizik eta pertsona moduan; horregatik bere taldekidetza etnikoa ez da garrantzitsua.

Etorkinen taldeen ikuspegitik ere, bost akulturazio-orientazio gerta daitezke: integrazioa, asimilazioa, separazioa, marjinazioa eta indibidualismoa. Aurretik azaldutako orientazioetatik berrikuntza separazioan eta marjinazioan egongo litzateke. Separazioan, etorkinen taldeak bere kultura eta hizkuntza mantendu dezake, harrera-taldeko kideekin harremanik izan gabe. Marjinazioan, etorkinek ezingo lukete beren kultura eta hizkuntza mantendu eta gainera ez lukete harrera taldeko kideekin harremanik izango.

Interactive Acculturation Model (IAM) izeneko eredu teorikoaren arabera (Bourhis, Moise, Perreault eta Senecal, 1997) akulturazioa norabide bikoitzeko prozesu bezala ulertzen da. Etorkinen kulturako kideek kultura berriarekiko dituzten jarrerak eta harrera-gizarteko kideek etorkinen kulturekiko dituzten jarreren interakzioa da aztertu beharrekoa. Bi taldekideen akulturazio-orientazioen konbinaketak talde arteko harreman mota bat eragiten dute. Bi taldeen ikuspegitik adostasuna dagoen kasuetan bakarrik izan daiteke baikorra sortzen den harremana. Baina beste kasuetan sortzen 
1. taula

Bourhis eta besteren (1994) Akulturazio eredu interaktiboa (IAM)

\begin{tabular}{cc}
\hline \multicolumn{2}{c}{ AKULTURAZIO-ORIENTAZIOAK } \\
\hline Harrera-taldea & Etorkinen taldea \\
Integrazioa & Integrazioa \\
Asimilazioa & Asimilazioa \\
Segregazioa & Separazioa \\
Esklusioa & Marjinazioa \\
Indibidualismoa & Indibidualismoa \\
\hline
\end{tabular}

den interakzioek talde arteko harremana problematikoa bihurtu dezakete, eta kasu okerrenetan talde arteko harremana gatazkatsua ere bihurtu daiteke.

2. taula

IAM Akulturazio eredu interaktiboa (Bourhis, et al., 1997)

\begin{tabular}{c|lllll}
\hline \multirow{2}{*}{ Harrera-gizartea: } & \multicolumn{5}{|c}{ Etorkin taldeak: } \\
\cline { 2 - 6 } & \multicolumn{1}{|c}{ Integrazioa } & Asimilazioa & Separazioa & \multicolumn{1}{c}{ Anomia } & Indibidualismoa \\
\hline Integrazioa & Adostasuna & Problematikoa & Gatazkatsua & Problematikoa & Problematikoa \\
Asimilazioa & Problematikoa & Adostasuna & Gatazkatsua & Problematikoa & Problematikoa \\
Segregazioa & Gatazkatsua & Gatazkatsua & Gatazkatsua & Gatazkatsua & Gatazkatsua \\
Exclusioa & Gatazkatsua & Gatazkatsua & Gatazkatsua & Gatazkatsua & Gatazkatsua \\
Indibidualismoa & Problematikoa & Problematikoa & Problematikoa & Problematikoa & Adostasuna \\
\hline
\end{tabular}

Ondorengo ikerketetan, autore batzuek seigarren orientazio bat gehitu zioten ereduari, integrazioaren orientazioan mota berri bat gehituz, gizarte hartzailearen aldetik egokitzapen bat aurreikusten duena, etorkinekiko harremanek eragindakoa. Autore horiek, integrazio eraldatzailea deitu diote azken orientazio horri (El-Geledi eta Bourhis, 2012; Safdar, Dupuis, Lewis, El-Geledi eta Bourhis, 2008).

Bestalde, IAM ereduak egokitzapenak izan ditu gure testuingurura aplikatua izan denean (ukipen-egoeran dagoen kultura eta hizkuntza gutxitu bat aztertzean, euskararen kasua). Honela, Azurmendi, Romay eta Valencia-k (1996) eredu berritu bat proposatu zuten, «Modelo de identificación etnosocial de la culturación» (MIESC) izenekoa. Eredu horrek identitate etnolinguistikoa barneratzearen garrantzia eransten du, talde etnikoen akulturazio-orientazioak azaltzerakoan. Euskal unibertsitarien artean ikerketa horren aplikazioan, indibidualismoa eta integrazioaren pare 
segregazioa agertzen zen kulturari zegokion eremuan, nahiz eta, beste eremuetan, enpleguan edo familia-ezkotzetan, integrazio- edo indibidualismo-orientazioak nagusi ziren (Azurmendi eta Larrañaga, 2008; Montaruli, Bourhis, Azurmendi eta Larrañaga, 2011; Larrañaga, García, Azurmendi eta Bourhis, 2016).

Akulturazio-orientazioak eskoletan aztertu direnean hainbat ikerketetan baieztatu da gazteek integrazioaren orientazioa hobesten zutela asimilazioaren aurrean (Phinney, Chavira eta Williamson, 1992; Cabrera et al., 2000; Berry et al., 2006; Briones, 2008; Nigbur, et. al., 2008; Graff Munaro, 2010). Dena den, beste ikerketa batzuetan, bestelako joerak azpimarratzen ziren, nahiz eta irakasleriak edo ikastetxeak ideologia integratzailea aitortu, ikasleen bizipenetan asimilazioaren emaitzetara zuzendutako joerak nabaritzen ziren (Rojo eta Recuerda, 2003).

\section{Identitate etnolinguistikoa}

Identitate soziala kategoria batzuen arabera (familia, lagunak, lana, sexua...) egituratzen da; kategoria horiek ahalbideratzen dute norbera talde sozial baten partaide sentitzea. Kategoria horiek norbanakoari ematen dizkiote besteengandik ezberdintzeko elementuak eta horrela identitate sozial propioa eskuratzen da. Kultura edota hizkuntza arteko ukipen-egoeratan hizkuntza eta kultura kategoria garrantzitsuak bilakatzen dira identitate soziala definitzerakoan. Ikuspegi honetatik Giles-ek eta Johnson-ek (1987) identitate etnolinguistikoaren teoria formulatu zuten, non hizkuntzaren eta identitatearen arteko erlazioa oso estua den; horrela, hizkuntzak oso rol garrantzitsua du identitatearen definizioan eta, alderantziz, identitateak eragiten die hizkuntzaren erabilerari eta hizkuntzekiko eta hiztun-taldeekiko jarrerei.

Espainiako Estatuan hainbat ikerketatan baieztatu da erkidego elebidunetan nagusiki hiru identitate mota topatu daitezkeela (Azurmendi, Bourhis, Ros eta García, 1998; Azurmendi eta Larrañaga, 2008; Montaruli, Bourhis, Azurmendi eta Larrañaga, 2011):

a) Identitate duala: identitate espainola eta autonomikoa integratzen dituena.

b) Identitate polarizatua identitate autonomikoaren alde: identitate autonomikoa altua eta identitate espainola baxua konbinatzen dituena.

c) Identitate polarizatua identitate espainolaren alde: identitate espainola altua eta identitate autonomiko baxua konbinatzen dituena.

Gainera, azterketa hauetan aurkitu zen identitateak talde arteko jarrerei eragiten ziela (Ros, Azurmendi, Bourhis eta García, 1999). Identitate polarizatua duten subjektuen kasuan (dela identitate autonomikoaren alde, dela identitate espainolaren alde) jarrera etnozentrikoak edo endotaldearen al- 
deko jarrerak topatu ziren. Aldiz, identitate duala duten subjektuen kasuan, jarrera positiboagoak topatu ziren exotaldeekiko; emaitza hauek bat egiten zuten beste ikerketa batzuetan lortutako emaitzekin (Ros, Cano eta Huici 1987; Ros, Huici eta Cano 1994).

Bestalde, kultura arteko ukipen-egoeratan, subjektuek aukera dute kultura bakarra kontuan hartzeko (identifikazio monokulturala) edo ukipenegoeran dauden kultura biak kontuan hartzeko (identifikazio bikulturala). Azkeneko aukerak ahalbideratzen du errealitate soziala interpretatzerakoan tresna bikoitza izatea, kultura bakoitzak ematen baitu errealitate soziala ulertzeko ikuspegi jakin bat. Konplexutasun kognitibo hau jarrera integratzaileekin lotzen da; berriz, identifikazio monokulturala lotzen da exotaldeekiko separazio- edota asimilazio-jarrerekin. Izan ere, identifikazio bikulturala garatzen denean asimilazio- edo separazio-orientazioak izateak disonantzia kognitiboa sortzen du; aldiz, identifikazio monokulturala garatzen denean asimilazio edo separazio bezalako jarrerek ez dute disonantziarik sortzen (Tadmor eta Tetlock 2006; Tadmor, Tetlock eta Peng 2009).

\section{Aniztasun kulturala Euskal Autonomia Erkidegoaren kontestuan}

Euskal Autonomia Erkidegoan (EAE) aniztasun kulturalaren testuinguruak aldaketak izan ditu azken urteetan. 2.000. urteaz geroztik, etorkinen biztanleria asko hazi da Euskal Herrian, honela, 2014. urtean 181.717 pertsona izatera iritsi arte, populazio osoaren \% 8,3 osatuz, Estatukoa baino kopuru txikiagoa, \% 9,7. Etorkin hartzaileen gehiengoa Hegoamerika, Europa eta Afrikatik etorria zen (Inmigrazioaren Euskal Behatokia, 2015).

Euskal eskolan eskolaratzen diren etorkinen seme-alaben kopurua ere hazi egin da 1998.urtezgero. Honela, 2013-14. ikasturtean Haur Hezkuntzan ikasleen artean 30.704 ziren ikasle etorkinak (Eustat, 2015a). Ikerketa honetako datu bilketa egin zen unean, 2011.urtean, Derrigorrezko Bigarren Hezkuntzan, ikasle etorkinek \% 8,4 suposatzen zuen etapa honetako biztanleriaz gain, 5.928 ikasle hain justu, nagusiki Hegoamerika, Afrikako Iparraldea eta Ekialdeko Europatik etorriak (Immigrazioaren Euskal Behatokia, 2011).

Azken urteetan, 2008. urteaz geroztik batik bat, krisi ekonomiko bat bizitzen ari gara, lanpostu askoren galera ekarri duena; honela, 2011. urtean langabezi tasa Euskal Herrian \% 10,6 zen, \% 13,8raino iritsiz 2013. urtean (Eustat, 2015b), Europar Batasuneko 27ko bataz bestekoaren gainetik kokatzen dena (\% 10,9), Espainiako langabezi tasaren azpitik egon arren $\%$ 26,3 (Eurostat, 2015).

Immigrazioaren Euskal Behatokiak, Ikuspegik, euskal gizartearen immigrazio berriarekiko jarreraren gain krisi ekonomikoak izan duen eragina aztertu du. Txosten honetan jasotzen denez, euskal gizartean jarrera integratzaileak nagusitzen diren arren, eta hedatzen doazen arren, aldi berean 
joera asimilazionista hedatua dagoela ikus daiteke, etorkinek bertako ohitura eta tradizioak bereganatu behar dituztela aipatuz edo legeak dionera egokitu behar dutela erlijio-praktiketan onartuz (Ikuspegi, 2014).

\section{IKERKERLANAREN HELBURU ETA HIPOTESIAK}

Gaur egungo eskolan kultur arteko harremanak gauzatzen dira; hala, bertako zein atzerritik etorritako ikasleak elkar harremanean daudenez, interesgarria litzateke aztertzea zer nolako jarrerak dituzten elkarrekiko. Hau da, batetik, bertako ikasleek ikasle etorkinekiko dituzten jarrerak aztertzea eta, bestetik, ikasle etorkinek bertako ikasleekiko dituztenak. Horregatik, ikerketa honen helburu nagusia da DBHko ikasleen kultur arteko jarrerak aztertzea, akulturazio teorian oinarrituz.

Helburu orokorretatik bi helburu zehatzagoak bereiz daitezke: batetik, ikasleen jatorriaren arabera (bertakoa edo etorkina izan) akulturazio orientazioak alderatzea eta, bestetik, ikasleen identitate etnolinguistikoaren (identitate duala edo polarizatua izan) eta akulturazioaren arteko harremana aztertzea.

Helburu zehatzetatik bi hipotesi formulatzen dira lan honetan:

- H1: DBHko ikasleen akulturazio-orientazioak, oro har, positiboak izatea espero da, hau da, ikasleek integrazio-orientazioan puntuazio altuagoak erakustea, asimilazio-, esklusio- edota marjinazio-orientazioetan baino. Bestalde, ikasleen jatorriaren arabera ez da espero alde esanguratsurik topatzea; hau da, ikasleek, bertako nahiz etorkin izan, akulturazio-orientazio berdintsuak erakutsiko dituzte.

$-\mathrm{H} 2$ : Identitate etnolinguistikoaren eta akulturazio-orientazioen arteko harremanari dagokionez, espero da ikasleen identitatearen arabera akulturazio-orientazioak ezberdinak izatea. Horrela, identitate duala duten ikasleek (kultura eta hizkuntza ezberdinak integratzen dituena), akulturazio-orientazio positiboagoak izatea espero da, identitate polarizatua duten ikasleek baino (kultura eta hizkuntza bakarrarekin identifikatzen direnak). Gainera, joera egonkor mantentzea espero da edozein dela ikasleen jatorria, bertakoa nahiz etorkin izan.

\section{METODOA}

\subsection{Parte-hartzaileak eta prozedura}

Ikerketa honetan 1.021 DBHko ikaslek hartu zuten parte, batez beste 14,45 urtekoak $(S=1,26)$. Ikasle horien \% 84.6 (863 subjektu) Euskal Herrian jaioak dira; \% 1,9 estatu espainolean jaioak dira (19 ikasle) eta 
\% 13,7 estatutik kanpo (139 subjektu). Ikasle gehienak \% 55,9 (571 subjektu) D ereduan ari dira ikasten, \% 26,2 (267 subjektu) B ereduan eta $\%$ 12,7 (130 ikasle) A ereduan.

Datuak biltzeko galdetegi bat erabili zen; horrela, ikasleek beraien ikasgelan galdetegia bete zuten eta horretarako gutxi gorabehera 50 minutu erabili zuten. Ikerketan parte hartzea borondatezkoa izan zen eta ikasle guztiei bermatu zitzaien anonimotasuna.

\subsection{Aldagaiak}

Ikerketa honetarako bi aldagai multzo neurtu ziren: identitatea eta akulturazio-orientazioak.

\section{Identitatea}

Bederatzi item erabiliz neurtu ziren euskal identitatea, identitate espainola eta jatorrizko herrialdearekiko identitatea. Identitatea neurtzean, hiru alderdi neurtu ziren (Bourhis \& Bougie, 1998):

a) Identitate orokorra: hiru item erabili ziren (markatu ezazu zure identifikazio maila: euskaldun bezala / espainol bezala / zure jatorrizko herriarekin).

b) Hizkuntza-identitatea: hiru itemen bidez (marka ezazu zure identifikazio maila: euskararekin / hizkuntza espainarrarekin / zure jatorrizko hizkuntzarekin).

c) Identifikazio-desioa: hiru galdera erabili ziren (zenbateraino nahi duzu: euskalduna izan / espainola izan / zure jatorrizko herrikoa izan).

Item guztietan Likert eskalak erabili ziren, non subjektuek adierazten duten beren identifikazio gradua, bost puntuko eskala erabiliz ( 1 batere ez / 2 gutxi / 3 erdizka / 4 nahiko / 5 asko).

\section{Akuturazio-orientazioak}

Akulturazio teoriari jarraituz, jarrera- edo akulturazio-orientazioak harreman-esparru ezberdinetan aztertu izan dira: lanean, familian, kulturan... DBHko ikasleentzako garrantzitsuena izan daitekeen esparrua aukeratu da azterketa honetan, hau da, kulturaren esparrua. Izan ere, lan eremua (lanpostuen banaketa jatorriaren arabera) edota familia eremua (jatorri ezberdinetako pertsonen arteko ezkontzak) ez dagozkie oraindik adin hauetako ikasleei.

Kultura eremuari dagokionez, zortzi orientazio neurtu ziren lan honetan Bourhisen eta besteren (1997) IAM eredu teorikoa jarraituz. Tresna hori aurrez erabilia izan zen euskal testuinguruan ikasle unibertsitarioekin 
egindako ikerketa batean (Azurmendi eta Larrañaga, 2008). Ikerketa hau egiteko tresna egokitua izan da DBHko testuingururako eta beronek bi norabidetako akulturazio-orientazioak neurtzen ditu: bertako ikasleen orientazioak etorkinekiko eta etorkinen orientazioak bertako ikasleekiko. Ondorengoak izan ziren tresnaren itemak:

a) Integrazioa: etorkinek beren kultura mantendu beharko lukete euskal gizartearena bereganatuz.

b) Integrazio eraldatzailea: euskal gizarteak bere kultura mantendu beharko luke, etorkinen jatorrizko kultura bereganatuz.

c) Asimilazioa: etorkinek beren kulturari uko egin beharko liokete eta euskal gizartearen bereganatu.

d) Segregazioa-Separazioa:

- Segregazioa: etorkinek beren kultura mantendu dezakete, baldin eta euskal gizartearen kulturan eragiten ez badute.

- Separazioa: etorkinek beren kultura mantendu dezakete, euskal gizarteko kulturak berarengan eraginik izan gabe.

e) Esklusioa-Marjinazioa:

- Esklusioa: euskal gizarteak ez du ezer irabazteko etorkinen eta beren kulturaren presentziarekin.

- Marjinazioa: etorkinek ez dute ezer irabazteko, euskal kulturaren presentziarekin.

f) Indibidualismoa: berdin dio etorkinek zein kultura gorde, pertsona bakoitza aske da nahi duen kultura aukeratzeko.

Item guztietan Likert eskalak erabili ziren, non subjektuek adierazten duten beren adostasun gradua bost puntuko eskaletan (1 batere ez ados / 2 nahiko ez ados / 3 erdizka / 4 nahiko ados / 5 erabat ados).

\section{EMAITZAK}

\subsection{Bertako ikasleen eta ikasle etorkinen akulturazio-orientazioak}

Subjektuen akulturazio-estrategiak beren jatorriaren arabera aztertzeko $6 \times 2 \mathrm{ko}$ bariantza-analisia egin zen. Lehenengo faktorean akulturazioorientazioak aztertu ziren (integrazioa, integrazio eraldatzailea, asimilazioa, segregazioa, separazioa, esklusioa, marjinazioa eta indibidualismoa) eta bigarrenean subjektuen jatorria (bertakoa eta etorkina).

Akulturazio-orientazioen eragin nagusia esanguratsua izan zen: $F(5,1015)=131,41 ; p<, 001 ; \eta^{2}=, 39$, eragin horren tamaina handia izanik. Post hoc analisiek akulturazio-orientazioak lau multzotan banatu zituzten. Subjektuek gutxien onartzen duten akulturazio-orientazioa asimila- 
zioa izan zen $(M=2,05)$. Bigarren maila batean integrazio tranformazioala agertu zen $(M=2,35)$, ondoren esklusioa-marginazioa $(M=2,66)$. Azpimarratzekoa da aipatutako orientazio hauek ez zutela gainditu eskalaren erdiko puntua (3 puntu). Onarpen gehiagoz agertu ziren integrazioa $(M=3,41)$, segragazioa-separazioa $(M=4,00)$ eta indibidualismoa $(M=4,01)$; azkeneko bi orientazioen artean alde esanguratsurik ez zen aurkitu.

3. taula

Akulturazio-orientazioak ikasleen jatorriaren arabera (Batez bestekoak eta desbideratze tipikoa — parentesi artean -)

\begin{tabular}{lc|ccc}
\hline \multicolumn{1}{c|}{ Akulturazio-Orientazioak } & $\begin{array}{c}\text { Lagin osoa } \\
n=1021 \\
M(S)\end{array}$ & $\begin{array}{c}\text { Bertakoak } \\
n=882 \\
M(S)\end{array}$ & $\begin{array}{c}\text { Talde arteko } \\
\text { aldeak } \\
M(S)\end{array}$ & $\begin{array}{c}\text { Etorkinak } \\
n=139 \\
M(S)\end{array}$ \\
\hline Indibidualismoa & $4,01(1,27) \mathrm{e}$ & $3,99(1,29)$ & $=$ & $4,17(1,15)$ \\
Segregazioa-Separazioa & $4,00(1,25) \mathrm{e}$ & $4,05(1,24)$ & $>$ & $3,70(1,25)$ \\
Integrazioa & $3,41(1,38) \mathrm{d}$ & $3,38(1,38)$ & $=$ & $3,56(1,35)$ \\
Esklusioa-Marjinazioa & $2,66(1,40) \mathrm{c}$ & $2,68(1,40)$ & $=$ & $2,49(1,36)$ \\
Integrazio transfor. & $2,45(1,41) \mathrm{b}$ & $2,40(1,39)$ & $<$ & $2,82(1,48)$ \\
Asimilazioa & $2,05(1,36) \mathrm{a}$ & $2,09(1,37)$ & $>$ & $1,80(1,25)$ \\
\hline
\end{tabular}

Oharra: a, b, c, d hizkiek adierazten dituzte alde esanguratsuak $(p<0,05)$ Bonferroni probaren arabera, non $\mathrm{a}<\mathrm{b}<\mathrm{c}<\mathrm{d}$. Jatorriaren araberako alderaketetan $(2$ eta 3 zutabeak) Student-en t estatisikoa erabili zen. Alde esanguratsuak adierazteko ikur matematikoak erabili dira $(><=)(p<0.05)$. Puntuazioen heina 1etik (erabat ez ados) 5era (erabat ados) izan zen.

Akulturazio-orientazioen eta subjektuen jatorriaren arteko elkar eragina ere esanguratsua izan zen $F(5,1015)=8,07 ; p<, 001 ; \eta^{2}=, 04$, nahiz eta elkarreragin honen tamaina txikia izan.

Orientazio bakoitza aztertuz, jatorriaren araberako ezberdintasun esanguratsuak hiru orientaziotan aurkitu ziren soilik, gainera, kasu guztietan eraginaren tamaina txikia izan zen. Aipatutako ezberdintasun esanguratsuak asimilazioan $[t(194,62)=2,53 ; p=, 012 ; d=0,23]$, segregazioa-separazioan $[t(1019)=3,06 ; p=0,002 ; d=$ ??] eta integrazio transformazionalean $[t(1019)=-3,31 ; p=, 001 ; d=-0,26]$ aurkitu ziren; aurreneko bi kasuetan bertako ikasleek etorkinak baino puntuazio altuagoak erakutsi zituzten; integrazio transformazionalean, aldiz, ikasle etorkinek puntuazio altuagoak eman zituzten. 


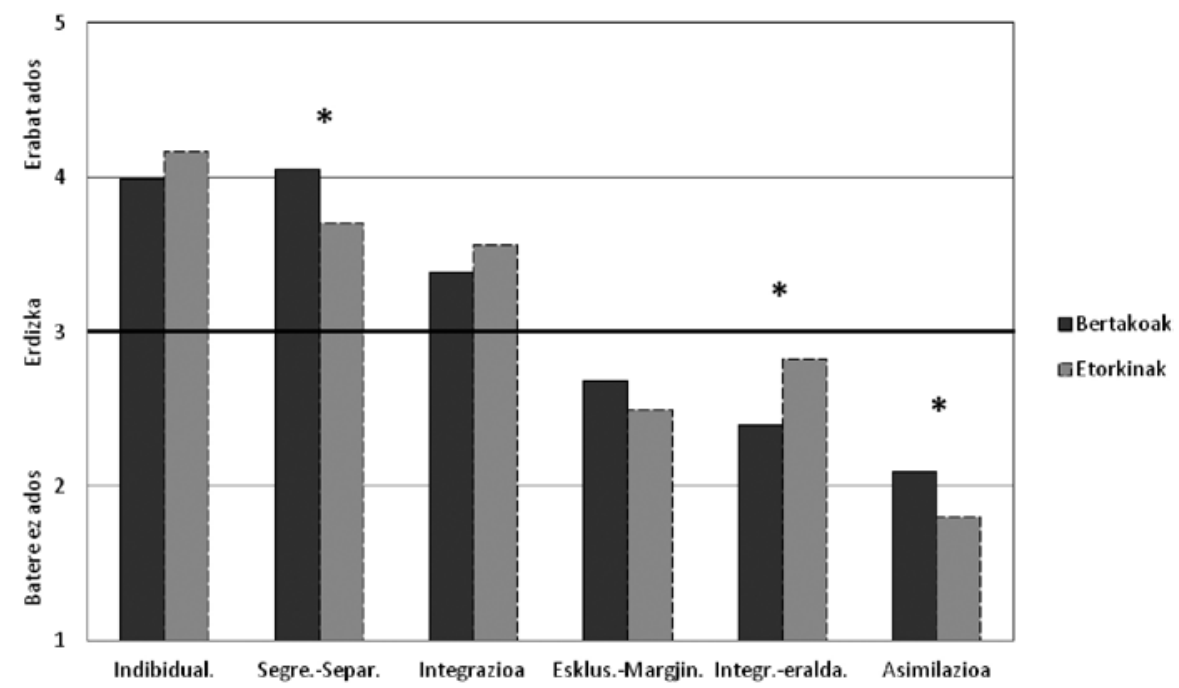

Oharra: Asteriskoek talde arteko alde esanguratsuak adierazten dituzte $(p<, 05)$ t probaren arabera.

1. irudia

Akulturazio-orientazioak ikasleen jatorriaren arabera

\subsection{Identitatea eta akulturazio-orientazioak}

Bigarren hipotesia testatzeko, ikasleen identitatea neurtzen zuten itemen egitura faktoriala aztertu zen. Horretarako, ikasleen jatorriaren araberako analisi bereziak egin ziren; alde batetik, bertako ikasleak aztertu ziren, eta bestetik, ikasle etorkinak.

\section{Bertako ikasleen identitatea eta akulturazio-orientazioak}

Bertako ikasleei dagokienez, analisi faktorialak bi faktore eman zituen; lehenengoak azaldu zuen bariantza osoaren \% 44,67. Faktore honetan agertu ziren euskal identitatea neurtzen zuten item guztiak. Item hauekin osatutako eskalak $0,79 \mathrm{ko}$ alpha koefizientea izan zuen, eta subjektuen puntuazioa batez beste 4,15 izan zen $(S=0,90)$. Bigarren faktoreak bariantza osoaren $\% 28,01$ azaldu zuen, eta bertan kokatu ziren identitate espainola neurtzen duten itemak. Item hauekin osatutako eskalak ,80ko alpha koefizientea izan zuen, subjektuek batez beste 3,48ko puntuazioa izan zutelarik $(S=1,12)$. Faktore bien artean bariantza osoaren $\% 72,68$ azaldu zuten. 
Identitateari buruzko itemen egitura faktoriala, bertako ikasleak (Pisu faktorialak)

\begin{tabular}{lcc}
\hline & 1 Faktorea & 2 Faktorea \\
\hline Identifikazioa euskaldun bezala &, 87 & \\
Zenbateraino nahi duzu euskalduna izan? &, 82 & \\
Identifikazioa euskararekin &, 82 &, 87 \\
Zenbateraino nahi duzu espainola izan? & &, 87 \\
Identifikazioa espainol bezala & &, 77 \\
Identifikazioa hizkuntza espainarrarekin & & \\
\hline
\end{tabular}

Oharra: analisi faktoriala Varimax errotazioaz egin zen, eta ,40 baino pisu gutxiago zuten itemak ezabatu ziren.

Eskala biak gurutzatuz, subjektuen taldekatzea egin zen lau identitate motatan. Horretarako, eskalak dikotomizatu egin ziren erdiko puntua erabiliz. Horrela, subjektuak puntuazioaren arabera bi multzotan bereizi ziren: 3 baino gehiago puntuatzen dutenak (identifikazio altua) eta 3 edo gutxiago puntuatzen dutenak (identifikazio baxua).

Identitate euskalduna eta espainolaren eskaletan emandako puntuazioen arabera ikasleak lau taldetan sailkatu ziren:

- Identitate duala: eskala bietan puntuazio altuak ( $>3)$ eman zutenak. Talde honetan agertu zen maiztasun altuena, 444 subjektu, bertako ikasleen \%50,3.

- Identitatea polarizatua euskalduna: subjektu hauek altu puntuatu zuten euskal identitatean $(>3)$ eta baxu idenitate espainolean $(\leq 3)$. Talde honetan 301 subjektu kokatu ziren, bertako ikasleen \%34,1.

5. taula

Bertako ikasleen sailkapena identitatearen arabera (Subjektu kopurua eta ehunekoa)

\begin{tabular}{c|c|c}
\hline \multirow{2}{*}{$\begin{array}{c}\text { Euskal } \\
\text { identitatea }\end{array}$} & \multicolumn{2}{|c}{ Identitate espainola } \\
\cline { 2 - 3 } & Baxua $(\leq 3)$ & Altua $(>3)$ \\
\hline \multirow{2}{*}{ Baxua $(\leq 3)$} & Definitu gabeko identitatea & Identitate polarizatua espainola \\
& $44(\% 5)$ & $93(\% 10,5)$ \\
\hline \multirow{2}{*}{ Altua $(>3)$} & $\begin{array}{c}\text { Identitate polarizatua euskalduna } \\
\text { 301 }(\% 34,1)\end{array}$ & $\begin{array}{c}\text { Identitate duala } \\
444(\% 50,3)\end{array}$ \\
\hline
\end{tabular}


- Identitatea polarizatua espainola: subjektu hauek altu puntuatu zuten identitate espainolean (>3) eta baxu euskal identitatean $(\leq 3)$, guztira 93 subjektu, bertako ikasleen \%10,5.

- Definitu gabeko identitatea: eskala bietan puntuazio baxuak $(\leq 3)$ eman dituztenak. Talde honetan 44 subjektu kokatu ziren, bertako ikasleen $\% 5$.

Ikusita definitu gabeko identitatearen taldearen maiztasuna (laginaren $\%$ 5) oso baxua dela, ondorengo analisietatik kanpo utzi zen; gauzak horrela, identitatearen eta akulturazio orientazioen arteko erlazio aztertzeko hiru identitate mota alderatu ziren: identitate duala, euskal identitatea eta identitate espainola.

Behin bertako ikasleak taldeetan sailkatu zirela, $6 \times 3$ ko bariantza-analisia egin zen. Lehenengo faktorean akulturazio-orientazioak sartu ziren eta bigarrenean identitate motak.

6. taula

Bertako ikasleen akulturazio-orientazioak identitate motaren arabera (Batez bestekoak eta desbideratze tipikoa - parentesi artean -)

\begin{tabular}{lccc}
\hline & \multicolumn{3}{c}{ Identitatea } \\
\cline { 2 - 4 } Akulturazio-orientazioak & Espainola & Euskalduna & Duala \\
& $n=93$ & $n=301$ & $n=444$ \\
& $M(S)$ & $M(S)$ & $M(S)$ \\
\hline Segregazioa & $3,54(1,39) \mathrm{a}$ & $4,22(1,14) \mathrm{b}$ & $4,10(1,20) \mathrm{b}$ \\
Indibidualismoa & $3,54(1,55) \mathrm{a}$ & $4,13(1,20) \mathrm{b}$ & $4,00(1,26) \mathrm{b}$ \\
Integrazioa & $3,08(1,36) \mathrm{a}$ & $3,38(1,42) \mathrm{b}$ & $3,47(1,35) \mathrm{b}$ \\
Esklusioa & $2,48(1,32)$ & $2,63(1,40)$ & $2,73(1,40)$ \\
Integra. trans. & $2,17(1,28)$ & $2,37(1,39)$ & $2,41(1,41)$ \\
Asimilazioa & $1,90(1,25)$ & $2,04(1,37)$ & $2,12(1,38)$ \\
\hline
\end{tabular}

Oharra: hizkiek $(\mathrm{a}, \mathrm{b})$ adierazten dituzte alde esanguratsuak $(p<0,05)$ Bonferroni probaren arabera, non $\mathrm{a}<\mathrm{b}$. Puntuazioen heina 1etik (erabat ez ados) 5era (erabat ados) izan zen.

Akulturazio-orientazioen eta identitatearen arteko elkarreragina ez zen esanguratsua izan, $F(10,1664)=1,08 ; p=, 27$, elkarreraginaren tamaina txikia izan arren, $\eta^{2}=, 015$. Akulturazio-orientazio bakoitza modu independentean aztertzeko, sei faktore bakarreko bariantza-analisi egin ziren. Sei orientazioetatik hirutan aurkitu ziren alde esanguratsuak identitatearen artean, nahiz eta kasu guztietan eraginaren tamaina oso txikia izan:

- Segregazioa $F(2,835)=11,46, p<, 001, \eta^{2}=, 03$.

- Indibidualismoa $F(2,835)=7,65, p=, 001, \eta^{2}=, 02$.

- Integrazioa $F(2,835)=7,65, p=, 040, \eta^{2}=, 01$. 
Gainontzeko akulturazio-orientazioetan (esklusioan, integrazio eraldatzailean eta asimilazioan) ez zen alde esanguratsurik aurkitu identitatearen arabera.

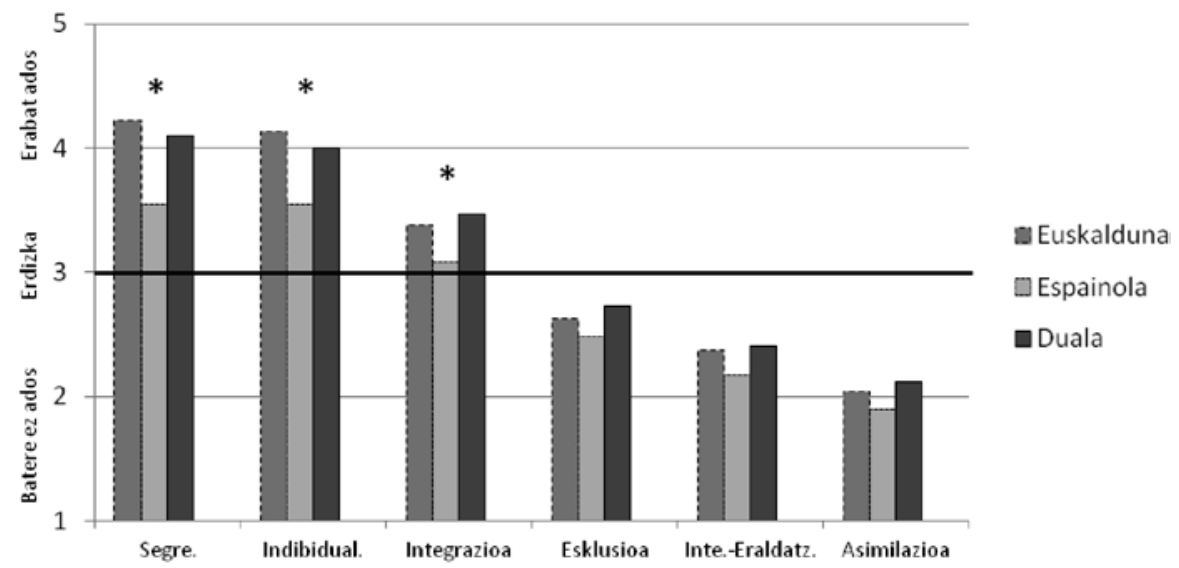

Oharra: Asteriskoek talde arteko alde esanguratsuak adierazten dituzte $(p<, 05)$ Bonferroni probaren arabera.

2. irudia

Bertako ikasleen akulturazio-orientazioak identitatearen arabera

(Batez bestekoak)

Identitate moten arteko konparaketak egiteko Bonferroni froga erabili zen. Horrela, segregazioan, indibidualismoan eta integrazioan identitate euskalduna edo duala duten subjektuek puntuazio altuagoak erakutsi zituzten identitate espainola dutenak baino (ikusi 6. taula).

\section{Ikasle etorkinen identitatea eta akulturazio-orientazioak}

Bertako ikasleekin jarraitutako prozedura berdina erabili zen ikasle etorkinen identitatearen egitura faktoriala aztertzeko eta subjektuak identitate taldeetan sailkatzeko (ikusi 6. eta 7. taulak).

Egindako analisi faktorialean hiru faktore agertu ziren; lehenengoak azaldu zuen bariantza osoaren $\% 31,46$, eta bertan agertu ziren identitate espainola eta euskaldunaren bi osagai: identifikazio orokorra eta identifikatzeko desioa. Lau item hauek osatutako eskalaren alpha koefizientea ,83 izan zen. Azpimagarria da faktore horretan identitate espainola eta euskalduna integratuta agertzen direla; gogoratu behar da hau ez dela gertatzen bertako ikasleen datuak aztertzean, non identitate espainola eta euskalduna bereizita agertzen diren. 


\section{7. taula}

Identitateari buruzko itemen egitura faktoriala, ikasle etorkinak

(Pisu faktorialak)

\begin{tabular}{lccc}
\hline & 1. Fak. & 2. Fak. & 3. Fak. \\
\hline Identifikazioa euskaldun bezala &, 84 & & \\
Zenbateraino nahi duzu euskalduna izan? &, 80 & & \\
Identifikazioa espainol bezala &, 73 & & \\
Zenbateraino nahi duzu espainola izan? &, 73 & & \\
Identifikazioa jatorrizko herriarekin & &, 80 & \\
Identifikazioa jatorrizko hizkuntzarekin & &, 74 & \\
Zenbateraino nahi duzu zure jatorrizko herrikoa izan? & &, 70 &, 88 \\
Identifikazioa euskararekin & & &, 45 \\
Identifikazioa hizkuntza espainarrarekin & & & \\
\hline
\end{tabular}

Bigarren faktorean kokatu ziren subjektuen jatorriko herrialdeari erreferentzia egiten dioten itemak: identifikazio orokorra, hizkuntzarekin eta identifikatzeko desioa. Faktore honek azaldu zuen bariantza osoaren $\%$ 24,37 eta item hauekin osatutako eskalaren alpha koefizientea ,79 izan zen.

Hirugarren faktorean bi item agertu ziren: identifikazioa euskararekin eta hizkuntza espainiarrarekin. Faktoreak azaldu zuen bariantza osoaren \%12,19 eta bi itemekin osatutako eskalaren alpha koefizientea ,15 izan zen.

Kontuan harturik azkeneko faktoreak soilik azaltzen duela bariantza osoaren \% 12 eta bere fidagarritasuna urria dela $(\alpha=, 15)$, subjektuak identiatearen arabera sailkatzeko aurreneko bi faktoreak erabili ziren.

8. taula

Ikasle etorkinen sailkapena identitatearen arabera

(Subjektu kopurua eta ehunekoa)

\begin{tabular}{|c|c|c|}
\hline \multirow{2}{*}{$\begin{array}{l}\text { Euskal-espainiar } \\
\text { identitatea }\end{array}$} & \multicolumn{2}{|c|}{ Identitatea jatorrizko herriarekiko } \\
\hline & Baxua $(\leq 3)$ & Altua $(>3)$ \\
\hline Baxua $(\leq 3)$ & $\begin{array}{l}\text { Definitu gabeko identitatea } \\
8(\% 5,8)\end{array}$ & $\begin{array}{c}\text { Jatorrizko herriarekiko identitate } \\
\text { polarizatua } 82(\% 59,0)\end{array}$ \\
\hline Altua $(>3)$ & $\begin{array}{l}\text { Euskal-espainiar identitatea } \\
5(\% 3,6)\end{array}$ & $\begin{array}{l}\text { Identitate duala } \\
\quad 44(\% 31,7)\end{array}$ \\
\hline
\end{tabular}


Definitu Gabeko identitatea eta Euskal-espainiar identitatea duten subjektuen maiztasun baxua kontuan harturik, hemendik aurrerako analisiek bi talde aztertuko dituzte soilik: Jatorrizko herriarekiko identitate polarizatua dutenak eta jatorrizko herriarekiko identitatea eta harrera-gizartearen identitatea integratzen dituztenak, alegia, identitate duala dutenak.

\section{Ikasle etorkinen akulturazio orientazioak identitatearen arabera (Batez bestekoak eta desbideratze tipikoa - parentesi artean -)}

\begin{tabular}{l|ccc}
\hline \multicolumn{4}{c}{ Identitatea } \\
\hline \multicolumn{1}{c}{ Akulturazio-orientazioak } & $\begin{array}{c}\text { Jatorizko herriarekiko } \\
\text { identitate polarizatua } \\
n=82\end{array}$ & $\begin{array}{c}\text { Talde } \\
\text { arteko } \\
\text { aldeak }\end{array}$ & $\begin{array}{c}\text { Identitate duala } \\
n=44 \\
M(S)\end{array}$ \\
\hline Indibidualismoa & $4.28(1.06)$ & $=$ & $4.18(1.22)$ \\
Separazioa & $3.68(1.27)$ & $=$ & $3.77(1.27)$ \\
Integrazioa & $3.40(1.36)$ & $=$ & $3.80(1.36)$ \\
Integra. trans. & $2.74(1.48)$ & $=$ & $3.09(1.58)$ \\
Marjinazioa & $2.45(1.32)$ & $=$ & $2.57(1.47)$ \\
Asimilazioa & $1.55(1.01)$ & $<$ & $2.09(1.49)$ \\
\hline
\end{tabular}

Oharra: Identitate moten araberako alderaketetan (2 eta 3 zutabeak) Student-en t estatisikoaren bidez egin ziren; alde esanguratsuak adierazteko ikur matematikoak erabili dira $(><=)(p<, 05)$. Puntuazioen heina 1etik (erabat ez ados) 5era (erabat ados) izan zen.

Akulturazio-orientazioen eta identitatearen arteko elkarreragina ez zen esanguratsua izan: $F(5,120)=1,33, p=, 25, \eta^{2}=, 053$.

Akulturazio-orientazioetan identitate-taldeak alderatzeko, sei $t$ froga egin ziren. Taldeen arteko alde esanguratsuak asimilazioan $t(64,6)=-2,42$; $p=, 034 ; d=-0.42$ aurkitu ziren soilik, non identitate duala duten subjektuek jatorrizko herriarekiko dutenak baino puntuazio altuagoak eman zituzten (dualekoek $M=2,09$ eta jatorrizko herriarekiko identitatea dutenek $M=1,55$. Eraginaren tamaina baxua-ertaina izan zen. 


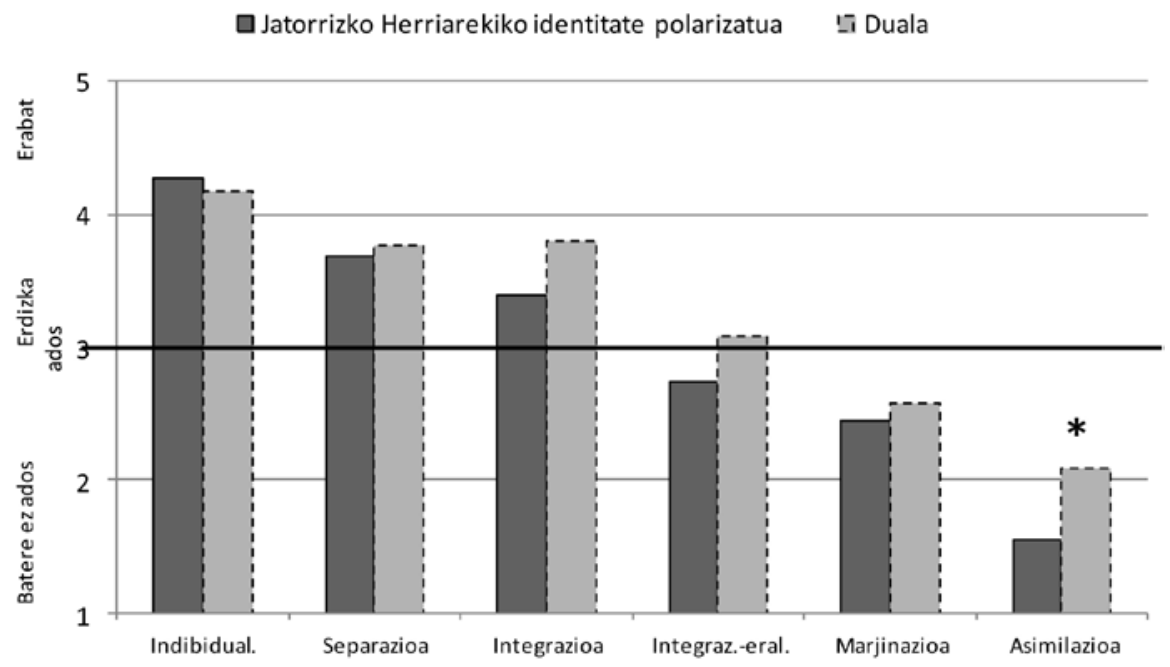

Oharra: Asteriskoak talde arteko alde esanguratsuak adierazten ditu $(p<, 05) t$ probaren arabera.
Ikasle etorkinen akulturazio-orientazioak identitatearen arabera
(Batez bestekoak)

\section{ONDORIOAK}

Bigarren hezkuntzako ikasleen artean gehien onartzen diren akulturazio-orientazioak hauek dira: indibidualismoa, segregazioa-separazioa eta integrazioa. Indibidualismoaren akulturazio-orientazioaren bidez, pertsonari aitortzen zaio nahi duen kultura aukeratzeko eskubidea: pertsona bakoitza aske da nahi duen kultura aukeratzeko. Taldekidetzak baino norbanakoak hartzen du garrantzia gaur egun; beraz, pertsona bera da talde lotura baino garrantzitsuagoa akulturazio-harremanetarako ere, gizarte modernoetan indartzen ari den norbanakoaren joerari jarraiki (Beck, 1999).

Baina aldi berean, taldekidetza etnikoak ere badu zer esanik, ikasleen akulturazio-orientazioen artean segregazio-separazio edo integrazio orientazioek ere onarpen handia agertzen baitute. Segregazio-separazioa orientazioa adieraztean, kultura talde ezberdinei, baita etorkinei ere, aitortzen zaie norbere kultura mantentzeko eskubidea, baina aldi berean, esplizitatzen da kultura batek beste kulturan eraginik ez izateko desira. Integrazioaren orientazioak ere onarpen zabala du. Orientazio hau adieraztean, etorkinek bi kulturak bereganatu ditzaten nahi da. Hau da, etorkinei jatorrizko kultura mantentzeko eskubidea onartzeaz gain, euskal gizartearen kultura bereganatzeko desira agertzen da. 
Badirudi beraz, euskal eskoletan kultura ezberdinen arteko zuzeneko ukipen-egoeratik sortzen diren harreman berriak nahiko baikorrak direla. Orokorrean, kultura-izaera ezberdinak mantentzeko jarrera aitortzen dute ikasle gehienek, nahiz eta separazio-segregazioak ez duen bi kulturen arteko harremana laguntzen.

Ikasleek ez dute ontzat ematen ezkorragoak diren bestelako orientazioak, asimilazioa edo marginazio-esklusioa kasu. Nahiz eta euskal gizartean oro har jarrera integratzaileekin batera joera asimilazionista ere hedatua dagoen, etorkinek bertako kultura bereganatzeko eskaera egiten dute (Ikuspegi, 2014). Badirudi eskola eremu babestu bat dela, gizartean asimilazioa onartzen den jarrera izan arren, ikasleek ez baitute jarrera honekin bat egiten. Nazioarteko beste kontestuetan egin diren ikasleen akulturazio-ikerketetan ere gazteek integrazioaren orientazioa hobesten dute asimilazioaren aurrean (Phinney, Chavira eta Williamson, 1992; Cabrera et al., 2000; Berry et al., 2006; Briones, 2008; Nigbur, et. al., 2008; Graff Munaro, 2010).

Emaitza hori izan daiteke ikastetxetan kultur artekotasunaren lanketaren ondorio. Gogoratu behar da Euskal Autonomia Erkidegoan Hezkuntza Sailetik eskola inklusiboa eta kulturartekoa bultzatzeko planaren helburuen artean dagoela hezkuntza-kulturan, -politika eta -jardueretan kulturarteko ikuspegia txertatzea (Eusko Jaurlaritza, 2012) eta egindako lanaren ondorioz Derrigorrezko Bigarren Hezkuntzako ikasleen akulturazio-orientazioak baikorrak direla eta orientatuta daudela etorkinen kulturaren errespeturako.

IAM ereduaren arabera (Bourhis, Moise, Perreault eta Senecal, 1997) akulturazioa norabide bikoitzeko prozesu bezala ulertzen denez, bi taldeek elkarrekiko dituzten orientazioen interakzioek talde arteko harreman mota ezberdinak eragin ditzakete. Bi ikuspegietatik nagusitzen diren orientazioen interakzioak zer nolakoak diren aztertu behar.

Harrera-gizarteko ikasleen ikuspegitik, etorkinekiko gehien adierazten dituzten akulturazio-orientazioak hauek dira: indibidualismoa, segregazioa eta integrazioa. Etorkinen taldeen ikuspegitik, berriz, honako hauek dira onartuenak: indibidualismoa, separazioa eta integrazioa.

Beraz, badirudi bi taldeetako ikasleen aldetik, integrazioa edo inbididualismoa bezalako orientazioak nagusitzen direnez, adostasuneko talde arteko harremanak agertzen direla. Indibidualismoaren orientazioa nagusitzean, ezaugarri pertsonalek eragiten dute ikasle hauen talde arteko harremanetan. Bestalde, integrazio orientazioa onartzean, etorkinek bi kulturak (beren jatorrizko kultura eta euskal gizarteko kultura) bereganatu ditzaten onartzen da, uste baitute etorkinen bikulturalismoak kulturaren pluraltasunean lagundu dezakeela. Orientazio horrek bat egiten duenean etorkinen ikuspegitik ere, adostasuneko talde-harremanak sortzen dira bikulturalismoa eraikitzen lagunduz.

Baina, segregazioa edo separazioa bezalako orientazioak agertzen diren kasuetan, bertako ikasle eta etorkinen arteko talde-harremanak gatazkatsuak gerta daitezke. Bertako ikasleen ikuspegitik segregazioa onartzean, 
etorkinekiko harremanak ekidin nahi dira etorkinen eraginez bertako kultura aldaraztea sahiesteko, nahiz eta onartzen duten etorkinek beren kultura mantentzea. Etorkinen ikuspegitik, berriz, separazioa onartzean, etorkinek beren kultura mantentzearen alde agertzen dira, euskal gizarteko kulturak beraien kulturan eraginik izan gabe; hau da euskal kulturak beraiengan eragina izatea sahiestu nahi da.

Onarpen maila baxuagoa duten akulturazio-estrategiak hauek dira: esklusio-marginazioa, integrazio transformazionala eta asimilazioa. Hauetatik bitan aurkitzen dira talde arteko alde esanguratsuak jatorriaren arabera, nahiz eta, efektuaren tamaina oso txikia izan. Horrela, bertako ikasleek altuago puntuatzen dute asimilazioan, non adierazten den etorkinek beren kulturari uko egin beharko lioketela eta euskal gizartearena bereganatu. Aldiz, ikasle etorkinek altuago puntuatzen dute integrazio transformazionalean, non euskal gizarteak bere kultura mantendu beharko bailuke etorkinen jatorrizko kultura bereganatuz.

Identitate etnolinguistikoaren egitura faktoriala aztertzean, bertako ikasleen artean lortutako emaitzek bat egiten dute beste ikerketa batzuetan aurkitu direnekin, non euskal eta espainiar identitateak bereizita agertzen diren (Azurmendi, García eta González, 1998; Azurmendi et al., 1998; Larrañaga et al., 2016). Identitate-taldeen maiztasuna aztertuta, identitate dualeko subjektuak laginaren erdia izateak ez du bat egiten orain arte topatu diren emaitzekin (Euskobarometroa, 2014, 2015); izan ere, maiztasun antzekoaz agertzen dira identitate duala eta soilik euskaldun bezala identifikatzen direnak. Edozein kasutan, kontuan hartu behar da ikerketa horietan lagina 18 urtetik gorako herritarrek osatzen dutela eta oraingo ikerketan, aldiz, Derrigorrezko Bigarren Hezkuntzako ikasleak aztertu direla; gainera, ikerketa honetan datuak biltzean etorkinen presentzia handia zuten ikastetxeak aukeratu ziren eta, horregatik, hautapen-soslaia egon daiteke; hortaz, emaitzak ezin dira orokortu populazio osora.

Ikasle etorkinen identitatearen egitura faktoriala aztertzean, bereizita agertu dira etorkinen identitatea, alde batetik, eta identitate espainola-euskalduna, beste aldetik. Badirudi ikasle etorkinek ez dutela bereizten identitate espainola eta euskalduna; horrela, ematen du identitate biak harreragizarteko ezaugarriak direla. Taldeen maiztasunari dagokionez, kolektibo handiena jatorrizko herriarekiko identitatea dutenek osatzen dute (laginaren erdia baino gehiago). Bestalde, identitate duala dutenek (jatorrizko taldearekin zein harrera-taldearekin identifikatzen direnak) ere maiztasun handiko taldea osatzen dute, ia laginaren herena izanik. Beste ikerketa batzuetan identitate duala izan da maiztasun altuena erakutsi duena adin hauetan (Berry, Phinney, Sam eta Vedder, 2006).

Identitatearen eragina akulturazio-orientazioetan ez da handia izan, batez ere ikasle etorkinen kasuan, soilik asimilazioan aurkitu baitira alde esanguratsuak. Bertako ikasleen artean, identitatearen arabera alde esanguratsuak aurkitu ziren hiru orientaziotan (segregazioan, indibidualismoan eta 
integrazioan) nahiz efektuaren tamaina oso txikia izan. Identitate duala eta identitate euskaldun polarizatua dutenen artean ez da inongo alde esanguratsurik aurkitu; aldiz, identitate polarizatu espainola dutenekiko alde esanguratsuak agertzen dira (Tadmor eta Tetlock 2006; Tadmor et al., 2009). Beraz, emaitzek ez dute gure hipotesia baieztatzen; izan ere, identitate duala duten subjektuek ez zuten akulturazio-orientazio hoberik erakusten identitate polarizatua dutenek baino. Emaitza honen oinarrian egon daiteke identitate polarizatuen elebitasuna eta kulturbitasuna; izan ere, aztertutako laginaren ikasle gehienak D edo B ereduan ikasten ari dira (\% 55,9a eta $\% 26,2$, hurrenez hurren), non euskara eta gaztelania lantzen diren eta baita euskal eta espainako kultura ere. Gauzak horrela, esan daiteke gure lagineko subjektu guztiak elebidunak eta kulturbidunak direla, nahiz eta identitateari dagokionez, batzuk kultura edo hizkuntza bakar batekin identifikatu, identitate polarizatua agertzen dutenak, alegia. Agian Tadmor eta Tetlock-ek aurreikusitako identitate dualeko subjektuen konplexutasun kognitiboa ageriagoa izan daiteke testuinguru elebakarretan, eta horregatik gure datuek ez dute hipotesia baieztatzen.

Bukatzeko, ikerketa honen mugak aipatu behar dira. Batetik, emaitzak ezin dira orokortu erabilitako lagina ez-probabilistikoa izan delako. Bestetik, datuak biltzeko Likert eskalen formatuko galdetegiak erabili dira. Etorkizunean komenigarria izan daiteke datu kuantitatiboak eta kuantitatiboak konbinatzea. Gure ikerketa-taldean horrelako datuak bilduak ditugu dagoeneko eta hurrengo lanetan argitara emateko asmoa dugu: horrela agian hobeto ulertuko dira gure testuinguruan immigrazioa dela-eta sortzen ari diren akulturazio-orientazioak. Bestalde, akulturazio-estrategiak aztertzean, eremu bakarra erabili da ikerketa honetan, kulturarena alegia. Ikerketa batzuek erakutsi dute akulturazio-estrategiak aldatu egiten direla eremuaren arabera; horrela, ekonomia eta lan-munduari dagokionez, asimilazioa da gehien aurkitu den orientazioa, eta kultura edo familia eremuan, separazioa (Berry eta Sam, 1997, 1996; Navas et al., 2007; Azurmendi eta Larrañaga, 2008). Akulturazio-estrategiak beste eremu batzuetan aztertu beharko lirateke akulturazioaren fenomenoaren ulermen osatuagoa izateko.

\begin{abstract}
This study analyzes the acculturation orientations of Basque students of secondary, and it compares the orientations by origin and ethno-linguistic identity. The results showed that the orientations of acculturation more accepted were individualism, separation-
\end{abstract}


segregation and integration. The orientations of both groups, native and immigrant students are coincident. Intergroup relations resulting from interactions of the acculturation of both groups would be quite positive except in cases of segregation-separation could be conflicting. Native students were classified into three groups according to their ethno-linguistic identity, dual identity, Basque identity polarized, and Spanish polarized identity. In turn, the immigrant students were classified into two groups: identity with the country of origin and dual identity. The results do not support the hypothesis that subjects with dual identity were more positive than subjects with polarized identity acculturation.

Keywords: Secondary education, processes of acculturation, Ethnolinguistic identity.

Este estudio analiza las orientaciones de aculturación de escolares vascos de Educación Secundaria, comparando las orientaciones de los alumnos según su origen y su identidad etnolingüística. Los resultados mostraron que las orientaciones de aculturación mas aceptadas fueron el individualismo, la segregación-separación y la integración. Las orientaciones de ambos grupos, alumnos autóctonos $e$ inmigrantes son coincidentes. Las relaciones inter grupo resultantes de las interacciones de las aculturaciones de ambos grupos serían bastante positivas salvo en los casos de segregación-separación que podrían resultar conflictivas. Los alumnos autóctonos fueron clasificados en tres grupos según su identidad etnolingüística: identidad dual, polarizada española y polarizada vasca. A su vez, los escolares inmigrantes se clasificaron en dos grupos: identidad con el país de origen e identidad dual. Los resultados no confirman la hipótesis de que los sujetos con identidad dual muestran orientaciones de aculturación más positivas que los sujetos con identidad polarizada.

Palabras clave: Educación secundaria obligatoria, procesos de aculturación, identidad etnolingüística.

Cette étude analyse les orientations d'acculturation des étudiants Basques dans l'Enseignement Secondaire, en comparant les orientations des élèves selon leur origine et leur identité ethnolinguistique. Les résultats ont montré que les orientations d'acculturation plus acceptées sont l'individualisme, la ségrégation-séparation et l'intégration. Les orientations des deux groupes, étudiants autochtones et immigrants, coïncident. Les relations intergroupes résultantes de l'interaction de ces deux groupes seraient assez positives, sauf dans les cas de ségrégation-séparation, qui pourraient être conflictuelles. Les étudiants autochtones ont été classés en trois groupes, selon leur identité ethnolinguistique: identité duale, identité polarisée basque, et 
identité polarisée espagnole. Les étudiants immigrants ont été classés en deux groupes: identité avec le pays d'origine et identité duale. Les résultats ne confirment pas l'hypothèse selon laquelle les sujets avec identité duale présenteraient des orientations d'acculturation plus positives que les sujets d'identité polarisée.

Mots-clé: Education Secondaire, acculturation, l'identité ethnolinguistique.

\section{ERREFERENTZIAK}

Azurmendi, M.-J. eta Larrañaga, N. (2008). La inmigración emergente en la Comunidad Autónoma Vasca (CAV) desde la sociedad de acogida: la aculturación. Non J.F. Morales, C. Huici, A. Gómez eta E. Gaviria (Zuz.), Método, teoría e investigación en psicología social. Madril: Pearson-Prentice Hall, or. 487-512.

Azurmendi, M.J., Bourhis, R.Y., Ros, M. eta García, I. (1998). Identidad etnolingüística y construcción de ciudadanía en las Comunidades Autónomas Bilingües (CAB) de España. Revista de Psicología Social, 13 (3), 559-589.

Azurmendi, M. J., García, I. eta González, T. (1998). Influencia del uso de las lenguas en contacto con la identidad social, en la Comunidad Autónoma Vasca (CAV). Revista de Psicología Social, 13 (1), 3-10.

Azurmendi, M.-J., Romay, J. eta Valencia, J. F. (1996). Identidad étnica y relaciones intergrupales en el mundo hispanohablante. In R.Y. Bourhis, J.P. Leyens, J.F. Morales eta D. Páez (Zuz.), Estereotipos, discriminación y relaciones entre grupos. Madril: McGraw-Hill, or. 241-284.

Beck, U. (1999). Hijos de la libertad. Buenos Aires: Fondo de Cultura Económica.

Berry, J.W. (1997). Inmigration, acculturation and adaptation. Applied psychology: An international review, 46 (1), 5-34.

Berry, J.W. (2001). A psychology of immigration. Journal of social issues, 57(3), 615-631.

Berry, J.W., Phinney, J.S., Sam, D.L. eta Vedder, P. (2006). Immigrant youth: Acculturation, identity, and adaptation. Applied psychology, 55 (3), 303-332.

Bourhis, R.Y. eta Bougie, E. (1998). Le modèle d'acculturation interactif: Une étude exploratoire. Revue Québécoise de Psychologie, 19, 75-114.

Bourhis, R.Y., Moise, L.C., Perreault, S. eta Senecal, S. (1997). Towards an interactive acculturation model: A social psychological approach. International journal of psychology, 32 (6), 369-386.

Briones, E. (2008). Proceso de aculturación de adolescentes inmigrantes residentes en España: estudio longitudinal de su identidad cultural y adaptación psicosocial. Doktorego-tesia, Universidad de Salamanca.

Cabrera, F., Espín, J.V., Marín, M.A. eta Rodriguez, M. (2000). Diagnóstico de la identidad étnica y la aculturación. Non M. Bartolomé et al. La construcción de la identidad en contextos multiculturales. 1. Edizioa. Madril: C.I.D.E./ M.E.C., or. 21-120. 
El-Geledi, S. eta Bourhis, R.Y. (2012). Testing the impact of the Islamic veil on intergroup attitudes and host community acculturation orientations toward Arab Muslims. International Journal of Intercultural Relations, 36 (5), 694706.

Euskobarometro (2014). Estudio periódico de la opinión pública vasca. Noviembre 2014. 2016ko otsailaren 9an kontsultatua. Eskuragarri: http://www.ehu. eus/documents/1457190/1525260/Euskobarometro+Noviembre+2014

Euskobarometro (2015). Estudio periódico de la opinión pública vasca. Mayo 2015. 2016ko otsailaren 9an kontsultatua. Eskuragarri: http://www.ehu.eus/ documents/1457190/1525260/EB_Mayo15.pdf

Eusko Jaurlaritza (2012). Ikasle etorkinentzako hezkuntza-arretarako plana, eskola-ereduinklusibo eta kulturartekoaren barruan. 2012-2015. Vitoria-Gasteiz : Eusko Jaurlaritzaren Argitalpen Zerbitzu Nagusia.

Eurostat (2015). Harmonised unemployment rate. 2015eko maiatzaren 14an kontsultatua. Eskuragarri: http://ec.europa.eu/eurostat.

Eustat (2015). Atzerrian jaiotako Euskal AEko ikasleak, espazio-eremuka, ikasmailaren eta sexuaren arabera. 2013/14. 2015eko maiatzaren 14an kontsultatua. Eskuragarri: http://eu .eustat.eus.

Eustat (2015). Euskal AEn 16 urteko eta gehiagoko biztanleen jarduera eta langabezia tasa. 2015eko maiatzaren 14an kontsultatua. Eskuragarri: http:// eu.eustat.eus.

Giles, H. eta Johnson, P. (1987). Ethnolinguistic identity theory: a social psychological approach to language maintenance. International Journal of the Sociology of Language, 68, 69-99.

Graff Munaro, J. (2010). Aculturación e identidad étnica: la integración social de los alumnos inmigrantes en las escuelas. Doktorego-tesia, Universidad de Salamanca.

Ikuspegi. Inmigrazioaren Euskal Behatokia. (2011). Etorkinak Euskal Autonomia Erkidegoko hezkuntza-sisteman. Inmigrazioaren Begirada, 41, 1-6.

Ikuspegi. Inmigrazioaren Euskal Behatokia. (2014). Immigrazioa eta krisiaren eragina. EAEko immigrazioari buruzko 2013 ko urtekaria. Bilbo: Euskal Herriko Unibertsitateko Argitalpen Zerbitzua.

Ikuspegi. Inmigrazioaren Euskal Behatokia. (2015). EAEn egoitza duten jatorri atzerritarreko biztanleak. Inmigrazioaren Begirada, 56, 1-5.

Ikuspegi. Inmigrazioaren Euskal Behatokia. (2015). Barometro 2015. Percepciones y actitudes hacia la inmigración extranjera. 2016eko urtarrilaren 28an kontsultatua. Eskuragarri: http://www.ikuspegi.eus/documentos/barometros/2015/ bar2015cas.pdf

Larrañaga, N., García, I., Azurmendi, M. J. eta Bourhis, R. Y. (2016). Identity and acculturation: interethnic relations in the Basque Autonomous Community. Journal of Multilingual and Multicultural Development, 37(2), 131-149.

Rojo, L. M. eta Recuerda, E. A. (Eds.). (2003). ¿Asimilar o integrar?: dilemas ante el multilingüismo en las aulas (54. zbk.). Madril: Hezkuntza Ministeritza.

Montaruli, E., Bourhis, R. Y., Azurmendi, M. J. eta Larrañaga, N. (2011). Social identification and acculturation in the Basque Autonomous Community. International Journal of Intercultural Relations, 35 (4), 425-439.

Navas, M., Rojas, A. J., García, M. C. eta Pumares, P. (2007). Acculturation strategies and attitudes according to the Relative Acculturation Extended Model 
(RAEM): The perspectives of natives versus immigrants. International Journal of Intercultural Relations, 31, 67-86.

Nigbur, D., Brown, R., Cameron, L., Hossain, R., Landau, A., Le Touze, D., Rutland, A. eta Watters, C. (2008). Acculturation, well-being and classroom behaviour among white British and British Asian primary-school children in the south-east of England: Validating a child-friendly measure of acculturation attitudes. International Journal of Intercultural Relations, 32 (6), 493-504.

Phinney, J. S., Chavira, V. eta Williamson, L. (1992). Acculturation attitudes and self-esteem among high school and college students. Youth and Society, 23 (3), 299.

Ros, M., Azurmendi, M. J., Bourhis, R. Y. eta García, I. (1999). Identidades culturales y lingüísticas en las Comunidades Autónomas Bilingües (CAB) de España: antecedentes y consecuencias. Revista de Psicología Social, 14 (1), 6986.

Ros, M., Cano, J. I. eta Huici, C. (1987). Language and Intergroup Perception in Spain. Journal of Language and Social Psychology, 6, 243-259.

Ros, M., Huici, C. eta Cano, J. I. (1994). Ethnolinguistic vitality and social identity: their impact on ingroup bias and social attribution. International Journal of the Sociology of Language, 108 (1), 145-166.

Safdar, S., Dupuis, D. R., Lewis, R. J., El-Geledi, S. eta Bourhis R. Y. (2008). Social axioms and acculturation orientations of English Canadians toward British and Arab Muslim immigrants. International Journal of Intercultural Relations, 32, 415-426.

Sam, D. L. (2006). Acculturation: conceptual background and core components. Non D. L. Sam eta J. W. Berry. The Cambridge handbook of acculturation psychology. 11-26. Cambridge, UK: Cambridge University Press, or. 21-120.

Tadmor, C. T. eta Tetlock, P. E. (2006). Biculturalism: A model of the effects of second-culture exposure on acculturation and integrative complexity. Journal of Cross-Cultural Psychology, 37, 173-190.

Tadmor, C. T., Tetlock, P. E. eta Peng, K. (2009). Acculturation strategies and integrative complexity: The cognitive implications of biculturalism. Journal of Cross-Cultural Psychology, 40, 105-139.

Van Oudenhoven, J. P., Ward, C. eta Masgoret, A. M. (2006). Patterns of relations between immigrants and host societies. International Journal of Intercultural Relations, 30 (6), 637-651. 